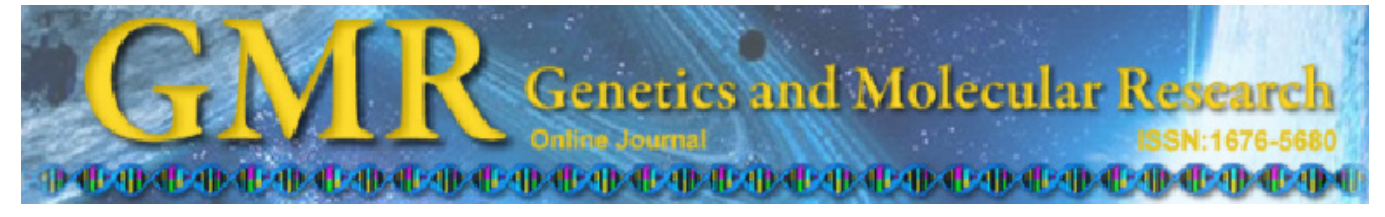

\title{
A duplex SYBR Green I real-time quantitative PCR assay for detecting Escherichia coli O157:H7
}

\author{
X. Yang*, H.W. Cheng*, L. Chen, J. Zhao, H.T. Chang, X.W. Wang, \\ H.Y. Liu, H.X. Yao, L.X. Zhang and C.Q. Wang \\ Institute of Poultry Diseases, Henan Agricultural University, \\ Zhengzhou, Henan, China \\ *These authors contributed equally to this study. \\ Corresponding author: C.Q. Wang \\ E-mail:wchuanq@163.com
}

Genet. Mol. Res. 12 (4): 4836-4845 (2013)

Received March 26, 2013

Accepted August 15, 2013

Published October 22, 2013

DOI http://dx.doi.org/10.4238/2013.October.22.3

\begin{abstract}
PCR and hybridization assays are widely used for the detection and identification of Escherichia coli serogroups and serotypes. We used these techniques for the detection of E. coli $\mathrm{O} 157: \mathrm{H} 7$, a dominant serogroup among $E$. coli strains that are considered major public health problems worldwide. We developed a quantitative PCR assay using SYBR Green I, based on the published sequences of the $r f b E$ and $f l i C$ genes from E. coli $\mathrm{O} 157: \mathrm{H} 7$. This method detected the E. coli $\mathrm{O} 157: \mathrm{H} 7$ $\mathrm{O}$ somatic antigen gene and the flagellar antigen gene simultaneously, with good specificity, sensitivity, and repeatability. The sensitivity of the assay was $2.95 \times 10$ copies $/ \mu \mathrm{L}$, which is $10^{3}$ times more sensitive than obtained with a conventional PCR. The intra-assay and inter-assay coefficients of variation were less than $2 \%$. We concluded that this duplex quantitative PCR assay is adequate for the identification and quantitative analysis of E. coli $\mathrm{O} 157: \mathrm{H} 7$. This provides a new identification method for clinical diagnosis of $E$. coli $\mathrm{O} 157: \mathrm{H} 7$ and for food safety analysis, as well as for molecular epidemiological studies of foodborne diseases.
\end{abstract}

Key words: Duplex; SYBR Green; Quantitative PCR;

Escherichia coli $\mathrm{O} 157: \mathrm{H} 7$ 


\section{INTRODUCTION}

The bacterium Escherichia coli $\mathrm{O} 157: \mathrm{H} 7$ is a worldwide threat to public health and has been implicated in many outbreaks of hemorrhagic colitis. It was conclusively identified as a pathogen in 1982 following its association with 2 food-related outbreaks of an unusual gastrointestinal illness. The organism is now recognized as an important cause of foodborne disease, with outbreaks reported in the United States, Canada, United Kingdom, Japan, and so on. Illness is generally quite severe, and can include 3 different syndromes, i.e., hemorrhagic colitis, hemolytic uremic syndrome, and thrombotic thrombocytopenic purpura (Orskov and Orskov, 1992; Nataro and Kaper, 1998; Paton and Paton, 1998b; Perna et al., 2001; Corrigan Jr. and Boineau, 2001). Most outbreaks have been associated with eating undercooked ground beef, unpasteurized milk and dairy products, vegetables or water, and contact with animal carriers or the environment (Gyles, 2007; Sánchez et al., 2010). In 1986, the organism was found in China and outbreaks of $E$. coli O157:H7 infections occurred in Anhui, Jiangsu, Henan, and Hubei Provinces of China from 1999 to 2000, in total, 20,000 cases were reported, including 177 deaths (Li et al., 2002; Zhang et al., 2007). Obviously, the disease has become a serious public health problem threatening people's welfare, and E. coli $\mathrm{O} 157: \mathrm{H} 7$ has a low infectious dose, with the average infectious dose being estimated at fewer than 50 organisms (Paton and Paton, 1998a; Chen et al., 2006; Sun, 2007; Sun et al., 2008), so it is very important to detect low levels of E. coli O157:H7.

Various diagnostic methods have been used for the identification of E. coli $\mathrm{O} 157: \mathrm{H} 7$, including phenotypic characterization, multiplex PCR, immunochromato-graphic strip, quartz crystal microbalance (QCM) piezoelectric immunobiosensor, and so on (Gannon et al., 1997; Paton and Paton, 1998a; Wang et al., 2007; Sun et al., 2008). However, these methods are not suitable for direct, quantitative detection of the organism in samples. Real-time PCR is a new method that allows the quantification of the target, and when combined with a rapid cycling platform, results can be generated in $30 \mathrm{~min}$ from the start of thermal cycling. Its simplicity, specificity, and sensitivity, together with its potential for high throughput and the ongoing introduction of new chemistries, more reliable instrumentation, and improved protocols, have made real-time PCR the benchmark technology for the detection of pathogenic organisms (Uhl et al., 2002).

The aim of the present study was the development of a duplex quantitative PCR (qPCR) assay using SYBR Green chemistry, which could not only quantify E. coli O157:H7 genomes in different samples, comparing its sensitivity with that of the conventional PCR, but also detect the E. coli $\mathrm{O} 157: \mathrm{H} 7 \mathrm{O}$ somatic antigen gene and the flagellar antigen gene simultaneously.

\section{MATERIAL AND METHODS}

\section{Bacterial strains}

A total of 34 strains were used in this study, including 7 E. coli $\mathrm{O} 157: \mathrm{H} 7$ and 27 other strains. The reference strain E. coli O157:H7 (CVCC248) was purchased from the China Control Institute of Veterinary Drug (CIVD). The other 6 Escherichia coli O157:H7 strains were isolated from domestic and free-ranging wild ruminants from Henan, Gansu, and Sichuan Provinces of China. Three strains of E. coli O157:H?, 6 strains of non-O157 E. coli, 1 strain of Shigella flexneri, and 1 strain of Citrobacter were included for comparison because they are closely related to E. coli $\mathrm{O} 157: \mathrm{H} 7$. In addition, 16 related strains representing the 
families Enterobacteriaceae, Enterococcaceae, Streptococcaceae, and Pasteurellaceae, which could represent a differential diagnostic problem, were used for specificity checking (Table 1).

\begin{tabular}{|c|c|c|c|c|c|}
\hline No. & Strain & Taxon & Origin & Host & Country \\
\hline 1 & CVCC248 & Escherichia coli O157:H7 & Feces & Unknown & China \\
\hline 2 & GSLT09 & E. coli $\mathrm{O} 157: \mathrm{H} 7$ & Feces & Camel & China \\
\hline 3 & HNWH09 & E. coli $\mathrm{O} 157: \mathrm{H} 7$ & Feces & Cow & China \\
\hline 4 & HNZZ09 & E. coli $\mathrm{O} 157: \mathrm{H} 7$ & Feces & Cow & China \\
\hline 5 & HNDF11 & E. coli $\mathrm{O} 157: \mathrm{H} 7$ & Feces & Goat & China \\
\hline 6 & GSLZ09 & E. coli $\mathrm{O} 157: \mathrm{H} 7$ & Feces & Yak & China \\
\hline 7 & HNZZJ10 & E. coli $\mathrm{O} 157: \mathrm{H} 7$ & Feces & Chicken & China \\
\hline 8 & HNZM11-1 & E. coli $\mathrm{O} 157: \mathrm{H} ?$ & Feces & Goat & China \\
\hline 9 & HNZM11-2 & E. coli $\mathrm{O} 157: \mathrm{H} ?$ & Feces & Goat & China \\
\hline 10 & HNZM11-3 & E. coli $\mathrm{O} 157: \mathrm{H}$ ? & Feces & Goat & China \\
\hline 11 & XXHJ-1 & Streptococcus spp & Palatine tonsil & Pig & China \\
\hline 12 & XXHJ-2 & Streptococcus spp & Palatine tonsil & Pig & China \\
\hline 13 & XXHJ-3 & Streptococcus spp & Palatine tonsil & Pig & China \\
\hline 14 & XXHJ-4 & Streptococcus spp & Palatine tonsil & Pig & China \\
\hline 15 & XXHJ-5 & Streptococcus spp & Palatine tonsil & Pig & China \\
\hline 16 & XXHJ-6 & Streptococcus spp & Palatine tonsil & Pig & China \\
\hline 17 & S735 & Streptococcus suis type 2 & Palatine tonsil & Pig & China \\
\hline 18 & $\mathrm{SH} 28$ & S. suis type 1 & Palatine tonsil & Pig & China \\
\hline 19 & Y15 & non-O157 E. coli & Feces & Goat & China \\
\hline 20 & Y18 & non-O157 E. coli & Feces & Goat & China \\
\hline 21 & ZK10 & non-O157 E. coli & Feces & Cow & China \\
\hline 22 & HJ & non-O157 E. coli & Feces & Chicken & China \\
\hline 23 & $\mathrm{RZ}$ & non-O157E. coli & Feces & Chicken & China \\
\hline 24 & SQ09 & non-O157 E. coli & Feces & Beef cattle & China \\
\hline 25 & CVCC464 & Pasteurella multocida & Unknown & Duck & China \\
\hline 26 & CVCC458 & P. multocida & Unknown & Chicken & China \\
\hline 27 & ZD01 & Shigella flexneri & Feces & Human & China \\
\hline 28 & EYu-NY & Enterococcus faecalis & Feces & Pig & China \\
\hline 29 & LH10 & Salmonella $\mathrm{spp}$ & Liver & Chicken & China \\
\hline 30 & CVCC 533 & S. pullorum & Heart-blood & Chicken & China \\
\hline 31 & C79 & S. pullorum & Liver & Chicken & China \\
\hline 32 & HF1 & Proteus mirabilis & Liver & Chicken & China \\
\hline 33 & HF2 & P. mirabilis & Liver & Chicken & China \\
\hline 34 & HY07 & Citrobacter & Unknown & Unknown & China \\
\hline
\end{tabular}

All strains were stored in nutrient broth (Difco Laboratories, Detroit, MI, USA) containing $10 \%$ sterile glycerol at $70^{\circ} \mathrm{C}$. Cultures were grown overnight $(18 \mathrm{~h})$ in Luria broth (Difco) at $37^{\circ} \mathrm{C}$.

\section{DNA preparation}

Genomic DNA was extracted from bacterial strains using a boiling method. Briefly, 1 $\mathrm{mL}$ overnight bacterial culture was pelleted by centrifugation at $12,000 \mathrm{rpm}$ for $5 \mathrm{~min}$ and resuspended in $100 \mu \mathrm{L}$ TE buffer (10 mM Tris-HCl, $1 \mathrm{mM}$ EDTA, pH 8.0). The suspension was placed in a boiling water bath for $5 \mathrm{~min}$, placed in an ice bath for $2 \mathrm{~min}$, and then centrifuged at 12,000 $\mathrm{rpm}$ for $5 \mathrm{~min}$. The supernatants were stored at $-20^{\circ} \mathrm{C}$ until they were used for the qPCR test.

\section{qPCR}

PCR primers were designed based on the $r f b E$ (S83460) and $f i C$ (NC_002655) gene sequences of $E$. coli $\mathrm{O} 157: \mathrm{H7}$ (Table 2). To construct a standard curve, as well as to ascertain 
the possible detection limits, traditional PCR was performed with the same primer pair. PCR products of $E$. coli $\mathrm{O} 157: \mathrm{H} 7$ were purified and cloned into the pMD 18-T vector (Takara) via TA cloning, according to manufacturer instructions. The copy number of the recombinant plasmids (pMD 18-T- $r f b E$ and pMD 18-T- $f l i C$ ) were adjusted to $2.95 \times 10^{11}$ copies $/ \mu \mathrm{L}$ as measured by a micro-ultraviolet/visible range spectrophotometer, respectively (NanoDrop ND1000). The recombinant plasmids were serially diluted 10 -fold to $2.95 \times 10^{10}$ copies $/ \mu \mathrm{L}$. Six dilutions, from $2.95 \times 10^{8}$ to $2.95 \times 10^{3}$ copies $/ \mu \mathrm{L}$, were used as standards to optimize the qPCR and to establish the standard curve.

\begin{tabular}{|c|c|c|}
\hline Genes & Sequence of primers & Size of product (bp) \\
\hline$r f b E$ & $\begin{array}{l}\text { F: CTACAGGTGAAGGTGGAATGGT (22 bp) } \\
\text { R: GTAGCCTATAACGTCATGCCAAT ( } 23 \text { bp) }\end{array}$ & 119 \\
\hline $\mathrm{fliC}$ & $\begin{array}{l}\text { F: CAAGTTGCCTGCATCGTCTA (20 bp) } \\
\text { R: TCAGCTTCAAAACGTGATGC ( } 20 \mathrm{bp})\end{array}$ & 168 \\
\hline
\end{tabular}

The qPCR mixture included $10 \mu \mathrm{L}$ SYBR Premix Ex Taq (TaKaRa Biotech), $0.4 \mu \mathrm{L}$ of each primer $(25 \mu \mathrm{M})$, and $2 \mu \mathrm{L}$ of each plasmid template in a total volume of $20 \mu \mathrm{L}$. The qPCR program, which was run on a LightCycler 1.5 (Roche), consisted of 1 min of Taq polymerase activation at $95^{\circ} \mathrm{C}$, followed by 40 cycles of $95^{\circ} \mathrm{C}$ for $4 \mathrm{~s}$ (denaturation), $55^{\circ} \mathrm{C}$ for $5 \mathrm{~s}$ (annealing), and $72^{\circ} \mathrm{C}$ for $12 \mathrm{~s}$ (extension), followed by a melting curve analysis. Each PCR was performed at least twice. Each PCR run included a positive control and no template control used as negative control to check for reagent contamination. After 40 amplification cycles, a melting analysis was carried out to verify the correct product by its specific melting temperature $(\mathrm{Tm})$. The thermal profile for the melting curve analysis consisted of a denaturation for 0 min at $95^{\circ} \mathrm{C}$, lowered to $61^{\circ} \mathrm{C}$ for $1 \mathrm{~min}$ and then increased to $95^{\circ} \mathrm{C}$ with continuous fluorescence readings. The standard curve and melting curve were established using the LightCycler software version 3.5.

\section{Specificity, sensitivity, and reproducibility of qPCR}

Thirty-four different bacterial strains (Table 1) and 1 control sample (deionized water) were utilized to assess the specificity of the qPCR assay. The qPCR detection limit was measured using $2.95 \times 10^{0}$ to $2.95 \times 10^{10}$ copies/ $\mu \mathrm{L}$ of standard recombinant plasmid and was compared to traditional PCR using the same primer pair.

To evaluate the intra-assay variability, 3 different known concentrations of standard plasmid $\left(2.95 \times 10^{6}, 2.95 \times 10^{7}\right.$ and $\left.2.95 \times 10^{8}\right)$ were amplified by performing the assay described above in triplicate. To evaluate the inter-assay variability, these plasmids were amplified again 2, 4, and 6 days later. For each experiment, the crossing point and coefficient of variation for each assay was calculated.

\section{RESULTS}

\section{Optimization of multiplex real-time PCR SYBR Green}

Primer pairs were designed to obtain distinguishable Tm for $r f b E$ and $f i C$. These 
primers were highly specific for $r f b E$ and $f l i C$ once submitted to in silico analysis by BLAST (data not shown). Traditional PCR produced the expected fragment of $119 \mathrm{bp}(\mathrm{rfbE})$ and 168 bp $(f i C)$. Sequence analysis showed that they were respectively identical to E. coli O157:H7 (S83460) and E. coli O157:H7 (NC_002655). Simplex real-time PCR SYBR Green amplification of DNA from E. coli O157:H7 strain CVCC248 yielded the same PCR products, respectively, and produced dissociation curves at $\mathrm{Tm}$ of $79.60^{\circ} \mathrm{C}$ (for $r f b E$ ) and $83.15^{\circ} \mathrm{C}$ (for $f l i C$ ), The combination of the designed primer pairs in one duplex SYBR Green I real-time PCR produced, for the same templates, dissociation curves at $\mathrm{Tm}$ of $79.65^{\circ} \mathrm{C}$ and $83.20^{\circ} \mathrm{C}$ (Figure 1), using $10 \mu \mathrm{L}$ SYBR Premix Ex Taq (TaKaRa Biotech), 10 pmol each primer, and thermal profile recommended by Taq polymerase manufacturer.

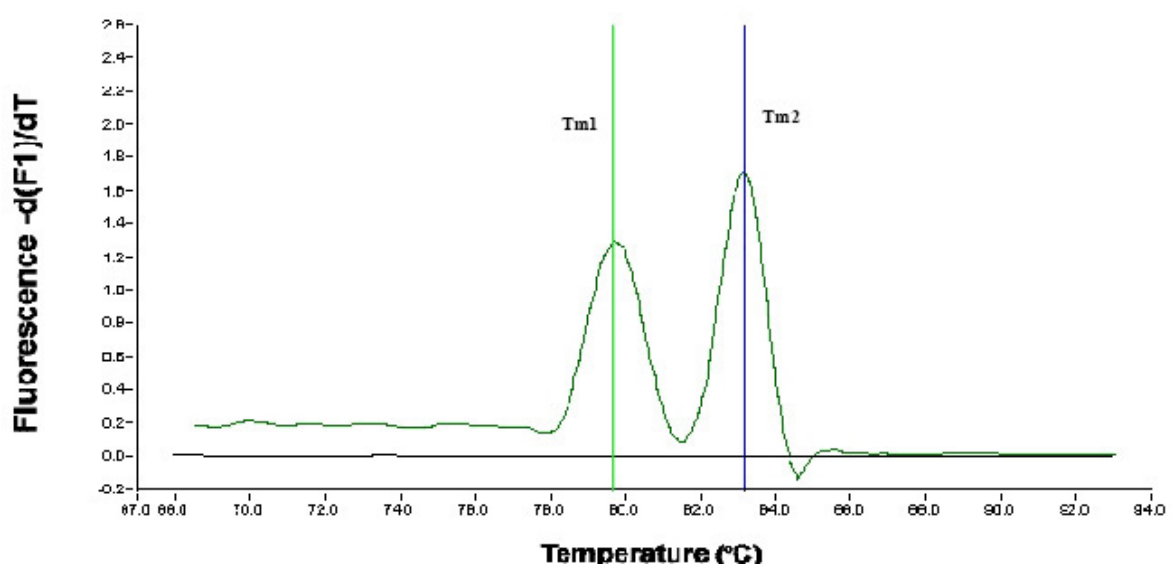

Figure 1. Melting curve of the SYBR Green I real-time PCR. Melting temperature: $\mathrm{Tm} 1=\mathrm{Tm}$ for $r f b E$; $\mathrm{Tm} 2=$ $\mathrm{Tm}$ for $f l i C$.

\section{Performance parameters of multiplex real-time PCR SYBR Green}

Serial dilutions of DNA from reference strains were used to test the response linearity and LOD of the method. The qPCR standard curve was plotted over a range of $2.95 \times 10^{8}$ to $2.95 \times 10^{3} \mathrm{copies} / \mu \mathrm{L}$ for both pMD 18-T- $r f b E$ and $\mathrm{pMD} 18$-T- $f l i C$ (Figure 2). The slope, intercept, and correlation coefficient were $-3.352,35.37$, and 1.000 , respectively. The efficiency was $98.76 \%$ according to the formula $\mathrm{E}=10^{-1 / 1 \text { lope }}-1$.

The specificity test showed that all DNA samples from 7 E. coli $0157: \mathrm{H} 7$ strains produced the expected positive results, whereas no positive result was detected when using templates from 27 other strains (Figure 3). Although there was an amplification signal from E. coli $\mathrm{O} 157: \mathrm{H}$ ? strains, the melting curve analysis showed that the Tm value of the products from $E$. coli $\mathrm{O} 157: \mathrm{H}$ ? was only $79.65^{\circ} \mathrm{C}$, but that from $E$. coli $\mathrm{O} 157: \mathrm{H} 7$ was $79.65^{\circ} \mathrm{C}$ and $83.20^{\circ} \mathrm{C}$ simultaneously (Figure 3 ). Other nonspecific amplifications and presence of primer dimers were not observed during the selectivity study. Thus, the specificity test showed $100 \%$ inclusivity and $100 \%$ exclusivity.

The detection limit of qPCR and traditional PCR was $2.95 \times 10^{1}$ copies/ $\mu \mathrm{L}$ (Figures 4 and 5) and $2.95 \times 10^{4}$ copies/ $\mu \mathrm{L}$ (Figure 6), respectively. The qPCR assay was $10^{3}$ times higher compared to conventional PCR. 


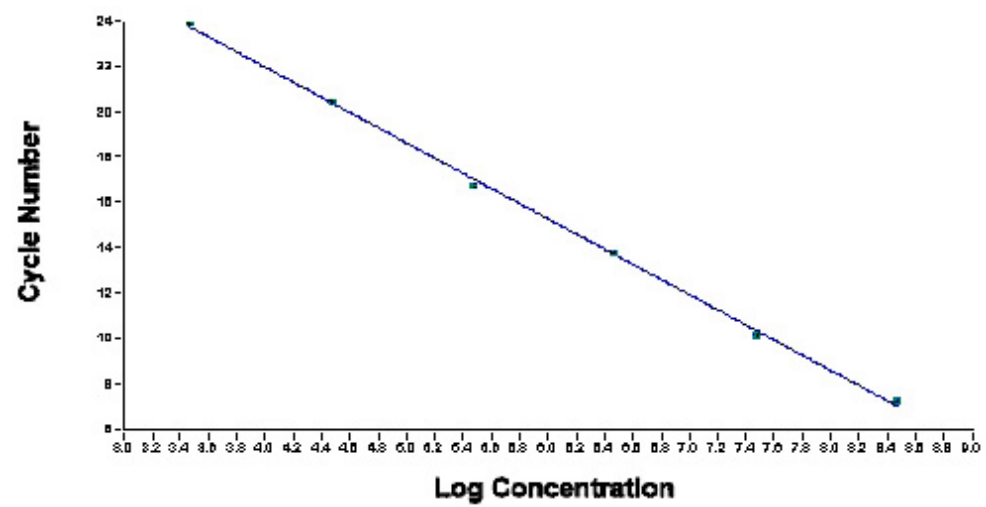

Figure 2. Standard curve of the SYBR Green I real-time PCR.

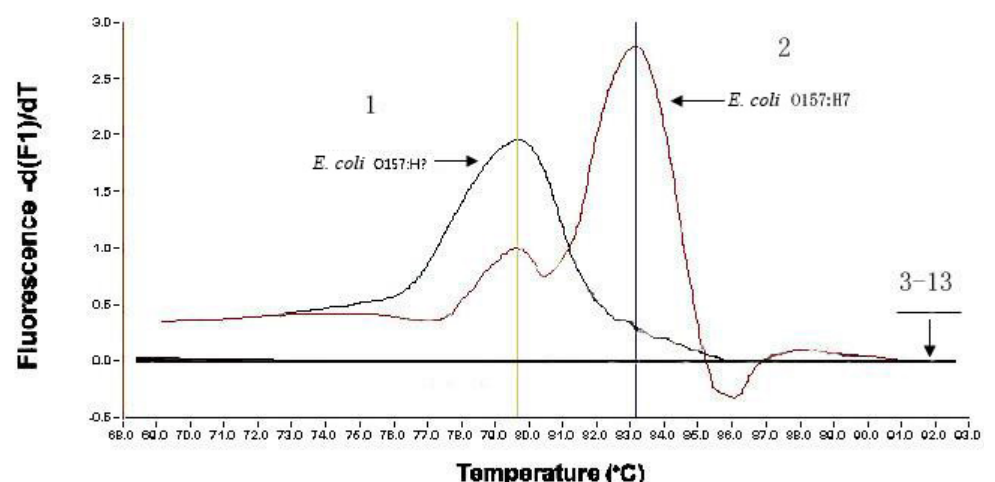

Figure 3. Specificity test of the SYBR Green I real-time PCR. Lanes 1 to $13=$ Escherichia coli O157:H? HNZM113, E. coli O157:H7 CVCC248, Streptococcus spp XXHJ-1, S. suis type $1 \mathrm{SH} 28$, S. suis type 2 S735, non-O157 E. coli Y15, Pasteurella multocida CVCC464, Shigella flexneri ZD01, Enterococcus faecalis E.Yu-NY, Salmonella pullorum CVCC 533, Proteus mirabilis HF1, Citrobacter HY07, blank control, respectively.

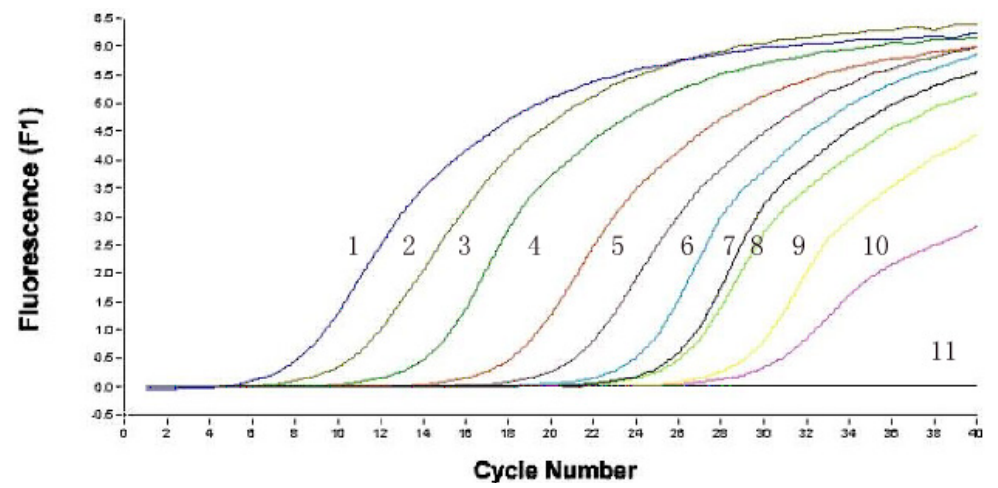

Figure 4. Amplification curves for detecting sensitivity by qPCR. Lanes 1 to $10=$ standard samples ranging from $2.95 \times 10^{10}$ to $2.95 \times 10^{1}$ copies $/ \mu \mathrm{L}$; lane $11=$ standard samples of $2.95 \times 10^{0}$ copies $/ \mu \mathrm{L}$ and blank control. 


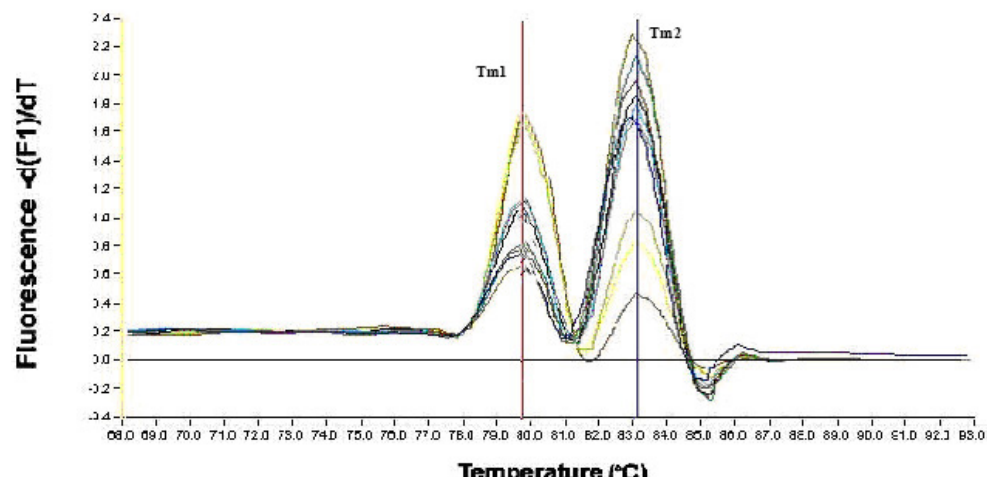

Figure 5. Melting curve for detecting sensitivity by qPCR. Melting temperature: $\mathrm{Tm} 1=\mathrm{Tm}$ for $r f b E ; \mathrm{Tm} 2=\mathrm{Tm}$ for $f i C$.

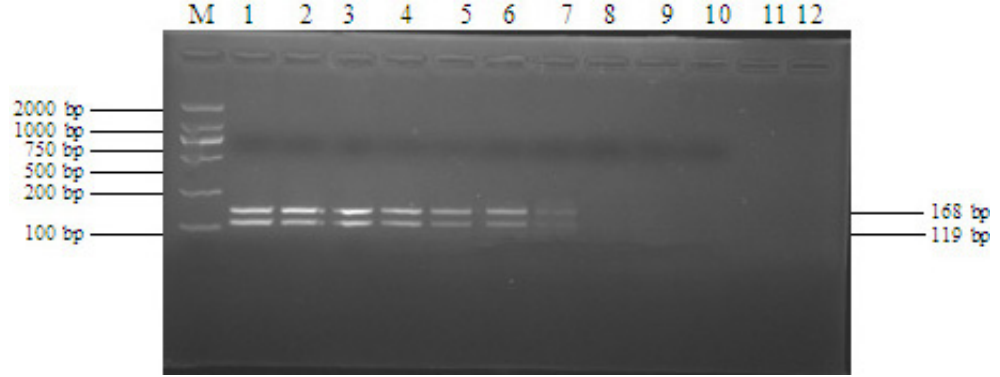

Figure 6. Sensitivity test of the amplification of common PCR. Lane $M=$ DL2000 maker; lanes 1 to $11=$ mixture template diluted $2.95 \times 10^{10}$ to $2.95 \times 10^{0}$ copies $/ \mu \mathrm{L}$, respectively; lane 12 = negative control.

Repeatability of the method was evaluated by testing 3 different concentrations of standard plasmids at different times, The intra- and inter-assay coefficients of variation were both less than $2.0 \%$ (Figure 7, Table 3).

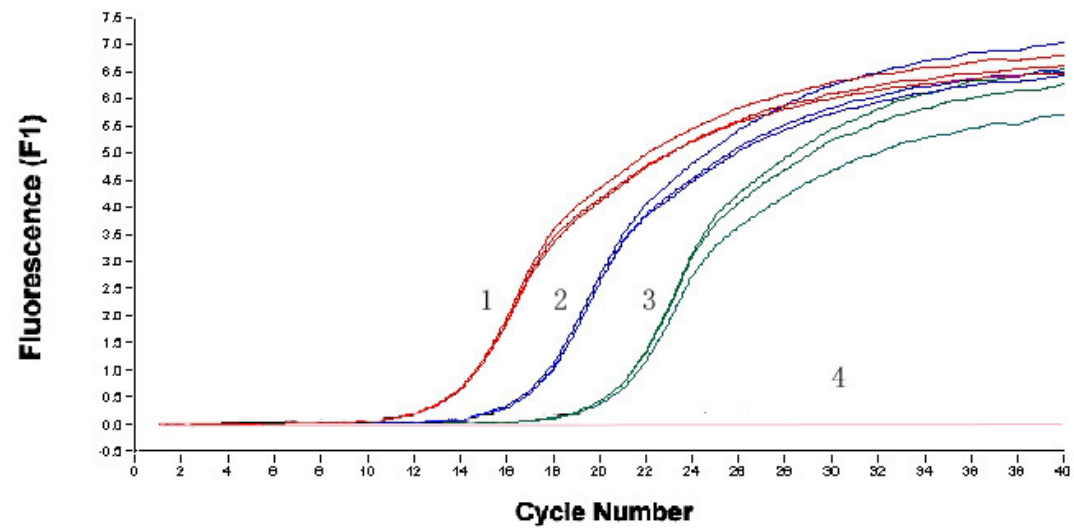

Figure 7. Reproducibility test of the SYBR Green I real-time PCR assay. Lanes 1 to $3=$ standard samples of 2.95 $\times 10^{8}, 2.95 \times 10^{7}$ and $2.95 \times 10^{6}$ copies $/ \mu \mathrm{L}$, respectively; lane $4=$ negative control. 
Table 3. Reproducibility of intra- and inter-assay by SYBR Green I real-time PCR (N = 3).

\begin{tabular}{|c|c|c|c|c|c|c|c|c|c|c|}
\hline \multirow{2}{*}{$\begin{array}{l}\text { Concentration of standard } \\
\text { plasmid (copies } / \mu \mathrm{L})\end{array}$} & \multicolumn{5}{|c|}{ Intra-assay Ct value } & \multicolumn{5}{|c|}{ Inter-assay $\mathrm{Ct}$ value } \\
\hline & 1 & 2 & 3 & Mean \pm SD & $\mathrm{CV} \%$ & 1 & 2 & 3 & Mean \pm SD & $\mathrm{CV} \%$ \\
\hline $2.95 \times 10^{6}$ & 13.20 & 13.21 & 13.22 & $13.21 \pm 0.01$ & $0.08 \%$ & 14.35 & 14.46 & 14.24 & $14.35 \pm 0.09$ & $0.63 \%$ \\
\hline $2.95 \times 10^{5}$ & 16.51 & 16.52 & 16.54 & $16.52 \pm 0.01$ & $0.06 \%$ & 17.60 & 17.80 & 17.24 & $17.55 \pm 0.23$ & $1.31 \%$ \\
\hline $2.95 \times 10^{4}$ & 20.00 & 20.03 & 20.06 & $20.03 \pm 0.03$ & $0.15 \%$ & 21.14 & 21.54 & 21.24 & $21.31 \pm 0.17$ & $0.80 \%$ \\
\hline
\end{tabular}

\section{DISCUSSION}

E. coli $\mathrm{O} 157: \mathrm{H} 7$ infection is a foodborne disease, and accumulating evidence indicates that it is related to consuming undercooked ground meat, unpasteurized milk and dairy products, fruit, vegetables, and juices, etc. Also, it is a worldwide problem for both public health and food safety. Therefore, it is absolutely necessary to develop a simple, rapid, sensitive, specific, inexpensive, and reproducible method to detect the pathogen, which is as important means to ensure food safety and prevent $E$. coli $\mathrm{O} 157: \mathrm{H} 7$ infection. The traditional methods for E. coli O157:H7 detection have limitations, such as time-consuming, lack of specificity and various interferences. Therefore, methods for rapid and specific detection are needed. PCR has been used to detect E. coli O157:H7. A number of E. coli O157:H7 genes have been targeted for diagnostic amplification by PCR, including those encoding the Shiga toxins (stxl and stx2), eaeA, hlyA, fliC (Gannon et al., 1997; Paton and Paton, 1998a; Osek, 2002; Sharma, 2002, 2006). However, quantification with PCR is still lacking in precision and further research is needed. Real-time PCR allows the quantification of the target, and when combined with a rapid cycling platform, results can be generated in 30 min from the start of thermal cycling. Because of the advantages of real-time PCR, many assays that perform better than the standard culture-based assays have been developed to detect pathogenic organisms (Uhl et al., 2002). At present, the most popular real-time PCR assay is based on the hybridization of a dual-labeled probe to the PCR product, and the development of a signal by loss of fluorescence quenching as PCR degrades the probe. Although this so-called "TaqMan" approach has proved to be easy to optimize in practice, the dual-labeled probes are relatively expensive (Maeda et al., 2003; Gubala, 2006; Kenar et al., 2007). In this study, the SYBRGreen I real-time PCR assay was successfully developed, which was based on the binding of the fluorescent dye SYBR Green I to the PCR product (Giglio et al., 2003; Gibellini et al., 2006). The qPCR assay could detect $E$. coli $\mathrm{O} 157: \mathrm{H} 7$ in various types of specimens, with a lower detection limit of $2.95 \times 10^{1} \mathrm{DNA}$ copies/ $\mu \mathrm{L}$. Thus, qPCR is more sensitive than traditional PCR $\left(2.95 \times 10^{4}\right.$ copies $\left./ \mu \mathrm{L}\right)$. Of the 34 samples from different genera of bacteria, only the 7 known E. coli $\mathrm{O} 157: \mathrm{H} 7$ samples produced the expected positive results using this assay. Moreover, the qPCR assay also showed excellent reproducibility, as demonstrated by the relatively fixed $\mathrm{Ct}$ value produced by the same concentration of plasmid template, and by the intra- and inter-assay coefficients of variation (both $<2.0 \%$ ). In addition, the results showed that the regression coefficient was -1.00 and the PCR amplification efficiency was $98.76 \%$. These results further confirmed the usefulness of this method.

In summary, a rapid, sensitive, specific, and reproducible duplex SYBR Green I realtime PCR method was developed and in-house validated, which could detect the E. coli O157:H7 $\mathrm{O}$ somatic antigen gene and the flagellar antigen gene simultaneously. Considering the perfor- 
mance parameters and the low cost of this SYBR Green approach, the reported method may be considered a suitable tool for laboratory diagnosis of E. coli $\mathrm{O} 157: \mathrm{H} 7$ and food safety determination. In particular, it represents an inexpensive method for testing a large number of samples, collected especially during the molecular epidemiological study of foodborne diseases.

\section{ACKNOWLEDGMENTS}

Research supported by the Henan Province Major Commonwealth Project (grant \#81100912300). We thank Mr. Yangke Liu and Dr. Heping Huangfu for their skillful technical assistance.

\section{REFERENCES}

Chen S, Huang KL, Xu WT, Li Y, et al. (2006). Real-time quantitative PCR detection of Escherichia coli O157:H7. J. Agric. Biotechnol. 14: 779-782.

Corrigan Jr JJ and Boineau FG (2001). Hemolytic-uremic syndrome. Pediatr. Rev. 22: 365-369.

Gannon VP, D’Souza S, Graham T, King RK, et al. (1997). Use of the flagellar H7 gene as a target in multiplex PCR assays and improved specificity in identification of enterohemorrhagic Escherichia coli strains. J. Clin. Microbiol. 35: 656-662.

Gibellini D, Gardini F, Vitone F, Schiavone P, et al. (2006). Simultaneous detection of HCV and HIV-1 by SYBR Green real time multiplex RT-PCR technique in plasma samples. Mol. Cell Probes 20: 223-229.

Giglio S, Monis PT and Saint CP (2003). Demonstration of preferential binding of SYBR Green I to specific DNA fragments in real-time multiplex PCR. Nucleic Acids Res. 31: e136.

Gubala AJ (2006). Multiplex real-time PCR detection of Vibrio cholerae. J. Microbiol. Methods 65: 278-293.

Gyles CL (2007). Shiga toxin-producing Escherichia coli: an overview. J. Anim. Sci. 85: E45-E62.

Kenar L, Ortatatli M, Karayilanoglu T, Yaren H, et al. (2007). Comparison of real-time polymerase chain reaction and conventional polymerase chain reaction methods for the rapid identification of Bacillus anthracis. Mil. Med. 172: 773-776.

Li H, Jing H, Pang B, Zhao G, et al. (2002). Study on diarrhea disease caused by enterohemorrhagic Escherichia coli O157:H7 in Xuzhou city, Jiangsu province in 2000. Zhonghua Liu Xing. Bing. Xue. Za Zhi. 23: 119-122.

Maeda H, Fujimoto C, Haruki Y, Maeda T, et al. (2003). Quantitative real-time PCR using TaqMan and SYBR Green for Actinobacillus actinomycetemcomitans, Porphyromonas gingivalis, Prevotella intermedia, tetQ gene and total bacteria. FEMS Immunol. Med. Microbiol. 39: 81-86.

Nataro JP and Kaper JB (1998). Diarrheagenic Escherichia coli. Clin. Microbiol. Rev. 11: 142-201.

Orskov F and Orskov I (1992). Escherichia coli serotyping and disease in man and animals. Can. J. Microbiol. 38: 699-704.

Osek J (2002). Rapid and specific identification of Shiga toxin-producing Escherichia coli in faeces by multiplex PCR. Lett. Appl. Microbiol. 34: 304-310.

Paton AW and Paton JC (1998a). Detection and characterization of Shiga toxigenic Escherichia coli by using multiplex PCR assays for stx1, stx2, eaeA, enterohemorrhagic E. coli hlyA, rfbO111, and rfbO157. J. Clin. Microbiol. 36: 598-602.

Paton JC and Paton AW (1998b). Pathogenesis and diagnosis of Shiga toxin-producing Escherichia coli infections. Clin. Microbiol. Rev. 11: 450-479.

Perna NT, Plunkett G, III, Burland V, Mau B, et al. (2001). Genome sequence of enterohaemorrhagic Escherichia coli O157:H7. Nature 409: 529-533.

Sánchez S, Martinez R, Rey J, Garcia A, et al. (2010). Pheno-genotypic characterisation of Escherichia coli O157:H7 isolates from domestic and wild ruminants. Vet. Microbiol. 142: 445-449.

Sharma VK (2002). Detection and quantitation of enterohemorrhagic Escherichia coli O157, O111, and O26 in beef and bovine feces by real-time polymerase chain reaction. J. Food Prot. 65: 1371-1380.

Sharma VK (2006). Real-time reverse transcription-multiplex PCR for simultaneous and specific detection of $r f b E$ and eae genes of Escherichia coli O157:H7. Mol. Cell Probes 20: 298-306.

Sun Y (2007). Rapid Detection of Enterohemorrhagic Escherichia coli O157. The doctoral dissertation of Jilin University.

Sun Y, Feng S, Guo XJ, Zhu Lw, et al. (2008). Development of immunochromatographic strip for detection of enterohemorrhagic Escherichia coli O157. Chin. J. Zoonoses 24: 356-359.

Uhl JR, Bell CA, Sloan LM, Espy MJ, et al. (2002). Application of rapid-cycle real-time polymerase chain reaction for the detection of microbial pathogens: the Mayo-Roche Rapid Anthrax Test. Mayo Clin. Proc. 77: 673-680. 
Wang LJ, Wu CS and Wang P (2007). Research and characterization of QCM immunobiosensor for Escherichia coli O157:H7 detection. Micronanoelectronic Fechnol. 44: 358-359,382.

Zhang JH, Lu QY, Ceng SY, Lu YY, et al. (2007). Rapid detection of Escherichia coli O157:H7 by using real-time fluorescence PCR assays. Chin. J. Zoonoses 23: 839-842. 